\title{
Reproductive effects in mink (Mustela vison) exposed to the pesticides Lindane, Carbofuran and Pentachlorophenol in a multigeneration study
}

\author{
A. P. Beard and N. C. Rawlings* \\ Department of Veterinary Physiological Sciences, Western College of Veterinary Medicine, \\ University of Saskatchewan, 52 Campus Drive, Saskatoon SK S7N 5B4, Canada
}

\begin{abstract}
The mammalian reproductive system is sensitive to exposure to endocrine disrupting chemicals, particularly during sexual maturation. The purpose of this study was to examine reproductive function in second and third generation male and female mink exposed to pesticides from conception to maturity. The mink were fed untreated feed or feed treated with Lindane ( $\left.1 \mathrm{mg} \mathrm{kg}^{-1} \mathrm{day}^{-1}\right)$, Carbofuran $\left(0.05 \mathrm{mg} \mathrm{kg}^{-1}\right.$ day $\left.{ }^{-1}\right)$ or Pentachlorophenol ( $1 \mathrm{mg} \mathrm{kg}^{-1} \mathrm{day}^{-1}$ ) from the time they were weaned. The second generation mink had also been exposed to the pesticides in utero and from their mother's milk as their mothers were similarly fed pesticides, from 3 weeks before breeding. The third generation mink were the offspring of mink (second generation females) who had themselves undergone long-term exposure to pesticides from conception onwards. Blood samples and endocrine tissues were obtained at necropsy from both generations of mink. No overt signs of toxicity were seen. The pesticides did not affect the percentage of mink mated. Lindane treatment reduced the proportion of mated mink that subsequently whelped $(P<0.1)$ and the litter size of mink that whelped $(P<0.05)$. Testis size was reduced in the Lindane-treated, third generation males $(P<0.05)$. Serum concentrations of cortisol, testosterone and oestradiol were not affected by any pesticide treatment; however, thyroxine concentration was reduced by Pentachlorophenol $(P<0.05)$. In conclusion, exposure of mink to Lindane from conception resulted in a decrease in reproductive efficiency when they were subsequently mated, leading to a $60 \%$ reduction in the number of kits born.
\end{abstract}

\section{Introduction}

The hypothesis has been put forward that exposure to certain persistent synthetic chemicals, which are known to interact with the mammalian endocrine system, may cause adverse effects on reproductive function in wildlife and humans (Colborn et al., 1993; Sharpe, 1995; Feldman, 1997). There is concern that irreversible effects may be induced when animals are exposed to endocrine disrupting chemicals during critically susceptible phases of sexual differentiation or development, such as Sertoli cell proliferation (Mably et al., 1992; Gray et al., 1994; Guo et al., 1995; Cooke, 1996). Most research has been focused on chemicals that have effects in systems controlled by steroid hormones (Nimrod and Benson, 1996; Guillette et al., 1996; Daston et al., 1997; Nagel et al., 1997). However, it has become apparent that other hormones that impinge on reproductive systems, such as the thyroid hormones, may also be sensitive to modulation by certain synthetic chemicals present in the environment (Cooke et al., 1996). The situation is complex, with multiple endocrine systems implicated in the mechanism of action of chemicals and effects that are dependent on the timing, duration, amount of exposure, and possible

*Correspondence and reprint requests.

Received 21 July 1997 synergistic interactions between chemicals. Therefore, it has become critical to re-evaluate certain classes of chemical in long-term multigenerational studies (Colborn, 1995; Kavlock et al., 1996).

Pesticides are released into the environment in large quantities each year and are routinely detected in air, dust, ground water and body tissues of animals and humans (Baukloh et al., 1985; Foster, 1995; Sonawane, 1995; Tate and Heiny, 1996; Thompson and Treble, 1996; Cessna et al., 1997). Many pesticides are lipophilic and bioaccumulate in lipid stores and tissues such as the mammary gland (Antunes-Madeira and Madeira, 1985; Kutz et al., 1991; Sitarska et al., 1995). They are mobilized along with the lipid during pregnancy and lactation, and may be passed to the developing fetus or offspring via placental transfer (Larsen et al., 1975; Khanna et al., 1991) and in milk (Pompa et al., 1994; Sonawane, 1995; Nair et al., 1996).

Mink are carnivores of agroforestry fringe habitats and are exposed to environmental contaminants that biomagnify within the food chain (Giesy et al., 1994; Heaton et al., 1995). Mink are seasonal breeders in which ovulation is induced by copulation (Sundqvist et al., 1989). Mink exhibit an obligatory period of delayed implantation, with the duration of gestation varying from 40 to 75 days. The blastocysts reach the uterus 7-8 days after fertilization and then enter a state of diapause which ends at implantation (for review see Hansson, 1947; 
Sundqvist ef al., 1989; Murphy and Douglas, 1992). The duration of pregnancy from implantation to parturition is about 30 days. The resting blastocyst may be particularly vulnerable to environmental contaminants, hence, mink have often been used in studies of reproductive toxicology, although multigeneration studies have not been undertaken (Aulerich et al., 1973; Calabrese et al., 1992; Crum et al., 1993; Heaton et al., 1995; Backlin and Bergman, 1995). In male mink, testicular recrudescence takes place each year before the breeding season (Basrur and Ramos, 1973).

In the present study, the effects of three pesticides: the organochlorines, Lindane (gamma-hexachlorocyclohexane) and Pentachlorophenol (PCP); and a carbamate, Carbofuran, on reproduction in mink were examined. These pesticides were chosen on the basis of their high usage in the Canadian prairies, and their known toxic effects (Spencer, 1982; Ecobichon, 1991). Both Lindane and PCP cause a decrease in whelping rate, but not litter size, after short-term exposure of female mink before breeding (Beard et al., 1997). This increase in embryo loss may well be endocrine-mediated. In the present study, the effects of long-term exposure to the three pesticides on reproductive function were examined in two generations of male and female mink, when pesticide exposure was continuous, from conception through growth and development, to sexual maturity.

\section{Materials and Methods}

\section{Animals}

The mink (demibuff colour phase, $n=135$ ) used in this study were initially housed with their mothers and littermates until weaning at 8 weeks of age. After weaning, they were housed individually under natural conditions of daylight and temperature at $52^{\circ}$ latitude. They were fed a pelleted complete ration (Pike Lake Fox Feed, Federated Co-op Feed Mill, Saskatoon, Saskatchewan) supplemented with $5-20 \%$ chicken offal (depending on the outside temperature) and mixed into a paste with water. Care and treatment of animals was according to the guidelines of the Canadian Council for Animal Care.

\section{Treatments}

The study consisted of an investigation of reproductive function in both second and third generation, male and female mink. Mink in each generation were fed either an untreated diet (CON), or a diet treated with Lindane (LIN; $1 \mathrm{mg} \mathrm{kg}^{-1}$ day $^{-1}$; Sanex Agro, Dundos, Ontario), Carbofuran (CAR; $0.05 \mathrm{mg}$ $\mathrm{kg}^{-1}$ day ${ }^{-1}$; Chem Agro, Etobicoke, Ontario) or Pentachlorophenol (PCP; $1 \mathrm{mg} \mathrm{kg}^{-1}$ day $^{-1}$; Sigma, St Louis, MO). Pesticide doses were chosen on the basis of previous studies (Ecobichon, 1991) and our own preliminary studies which indicated that they were approximately $10 \%$ of the doses that caused a minimal effect after acute exposure (such as a temporary reduction in feed intake). Doses were designed to be low enough to avoid any overt toxicity, but high enough to show any potential effects of long-term exposure on reproduction. The pesticides were sprayed evenly onto a weekly supply of the pelleted ration which was thereafter mixed daily with the chicken and water before feeding. Treated feed was kept in darkness at $\leq 4^{\circ} \mathrm{C}$ before being fed.

The second generation mink were the offspring of females who had been fed treated or untreated feed continuously, from 3 weeks before breeding until weaning of the present group of mink ( 8 weeks post partum). The second generation female mink (CON, $n=10$; LIN, $n=10$; CAR, $n=8$; PCP, $n=8$ ) were maintained on treated feed from weaning, throughout growth, mating (to untreated males), pregnancy, lactation and for a further 3 months after the end of lactation until they were killed. The second generation males (CON, $n=10$; LIN, $n=8$; CAR, $n=10$; PCP $n=6$ ) were maintained on treated feed until they were killed when their testis development was maximal at about 42 weeks of age. The third generation mink were the offspring of the second generation females. Third generation males (CON, $n=8$; LIN, $n=8$; CAR, $n=4$; PCP, $n=8$ ) were again maintained on treated feed until reaching sexual maturity in their first breeding season. Third generation females (CON, $n=10$; LIN, $n=8$; CAR, $n=9$; PCP, $n=10$ ) were maintained on treated feed until they reached full adult body size at 30 weeks of age, when they were killed. Thus, all mink were effectively treated continuously from conception to maturity, although the third generation mink were born to mothers treated from conception, whereas the second generation mink were born to mothers who were exposed from just before mating.

Body weight was recorded every 2 weeks until the kits were fully grown and then at 4 week intervals, except during pregnancy, when handling was avoided. Feed intake was also monitored during the first 4 months of the study by weighing the amount of wet feed given and subtracting any feed wasted.

\section{Mating}

The second generation female mink were mated, according to normal ranch practice of an initial mating, followed 7 or 8 days later by a second mating. From March 6 , and continuing each day until April 2, one or two females from each group were selected randomly to be mated as described by Beard et al. (1997). The procedure was repeated with any unmated females on up to six further occasions, a number of days later, and if mating still did not occur, the females were classified as non-breeding females. During the whelping period, the mink were checked at least twice a day to determine whether they had whelped. If whelping was suspected, the litter size was counted quickly without disturbing the nest. The litter was then counted and weighed every 2 weeks until weaning (8 weeks post partum).

\section{Testicular development}

Testicular development was monitored in the second and third generation males at 2 week intervals on four separate dates from mid-December to the end of January (the period of maximal testicular growth; DiGregorio et al., 1994). Mink were sedated with $10 \mathrm{mg}$ ketamine $\mathrm{kg}^{-1}$ (Vetlar, Vetrapharm, London, Ontario) and I mg xylazine $\mathrm{kg}^{-1}$ (Rompun, Bayvet, Etobicoke, Ontario) i.m. so that they could be handled less stressfully. The left testis was located in the scrotum and its 
length was measured using calipers. This method overestimates the true testicular length as it includes the scrotal wall. The mink were killed after the final testicular measurement at the end of January, when the serum concentration of testosterone was expected to be maximal (DiGregorio et al., 1994).

\section{Necropsy}

At necropsy in late January, all second and third generation mink were sedated with $20 \mathrm{mg}$ ketamine $\mathrm{kg}^{-1}$ and $2 \mathrm{mg}$ xylazine $\mathrm{kg}^{-1}$ i.m. A blood sample was collected by cardiac puncture, and the animals were killed by an intracardiac injection of T61 (Hoechst, Regina, Saskatchewan) and necropsied. In the second generation male mink, the masses of the left and right testes and epididymides were recorded and samples of tissue were fixed in Bouin's fixative. The masses of the prostate/ampulla, thyroid, adrenal, kidney, heart and brain were also recorded and samples, as well as samples of pancreatic, liver and pituitary tissue, were fixed in normal buffered formalin. The mass of the penis was also recorded, as were the dimensions of the testes and penis. In the second generation females, the masses of the ovaries, oviduct, uterus, pituitary, thyroid, parathyroid and adrenals were recorded and samples, as well as a sample of pancreatic tissue, were fixed in normal buffered formalin. The masses of the heart, brain, liver and kidney were also recorded. Tissues were dehydrated and embedded in paraffin wax for sectioning, mounted and stained with haematoxylin and eosin before histopathological examination. In the third generation mink, the same tissues were weighed and measured; however, in the third generation females, no tissues were examined histologically and in the third generation males, only the endocrine and reproductive tissues were examined.

Additional samples of liver $(n=8)$ and samples of fat from around the kidney $(n=8)$ were obtained from the third generation females and analysed by gas chromatography (J. R. Patterson, Agriculture Canada, Saskatoon, Saskatchewan) to obtain the tissue content of PCP and Lindane (MacNeil et al., 1990, 1991).

\section{Hormone assays}

Blood samples collected at necropsy were allowed to clot overnight at room temperature and serum was separated by centrifugation at $1500 \mathrm{~g}$ for $10 \mathrm{~min}$, and stored at $-20^{\circ} \mathrm{C}$ until assayed. Serum concentrations of oestradiol and thyroxine, from both the second and third generation male and female mink, were all measured in a single assay. Serum concentrations of oestradiol were measured as described by Ravindra et al. (1994). The limit of sensitivity was $3.7 \mathrm{pmol} \mathrm{I}^{-1}$ and the intra-assay coefficients of variation for reference sera with oestradiol concentrations of 34.2 and $68.3 \mathrm{pmol} \mathrm{l}^{-1}$ were 9.7 and $7.3 \%$, respectively. Serum concentrations of thyroxine were measured as described by Allen et al. (1995). The limit of sensitivity was $5 \mathrm{nmol} \mathrm{l}^{-1}$ and the intra-assay coefficients of variation for reference sera with thyroxine concentrations of 25.9 and $59.4 \mathrm{nmol}^{-1}$ were 7.9 and $2.5 \%$, respectively. Serum concentrations of cortisol for the second generation females were measured as described by Kingsbury and Rawlings
(1993). The limit of sensitivity was $12.4 \mathrm{nmol}^{-1}$ and the intra-assay coefficients of variation for reference sera with cortisol concentrations of 118.7 and $30.3 \mathrm{nmol} \mathrm{l}^{-1}$ were 10.6 and $13.5 \%$, respectively. Serum concentrations of testosterone for the male mink were measured as described by DiGregorio et al. (1994). The limit of sensitivity was $0.1 \mathrm{nmol} \mathrm{l}^{-1}$ and the intra-assay and interassay coefficients of variation for reference sera with testosterone concentrations of 4.03 and $7.67 \mathrm{nmol}$ $1^{-1}$ were 10.3 and $10.8 \%$, and 8.8 and $9.3 \%$, respectively.

\section{Histopathological examination}

Each tissue was examined for any potential treatment-related lesions. When a characteristic of a tissue was observed to be outside the normal histological limits, the severity of the lesion was evaluated as follows: $0-1=$ minimal, $1-2=$ mild, $2-3=$ moderate, 3-4 = marked. Within any of the above categories, the extent of the lesion within the tissue was scored as follows: for example, $1.25=$ mild focal, $1.50=$ mild diffuse, $1.75=$ mild multifocal. Therefore, each tissue was given a score ranging from 0 to 4 .

\section{Statistical analysis}

Whelping rate is expressed as the number of mated mink that subsequently whelped. Litter size is expressed as the mean number of kits at birth, where data from only the females that produced litters were considered. The proportion of mink in each treatment group mating or whelping was compared with the proportion in the control group by chi-squared analysis (Sokal and Rohlf, 1969). The effects of treatment on litter size and hormone concentration were examined by Student's $t$ test (single comparisons of each treatment group with the control group) (True Epistat, Epistat Services, Richardson, TX). The data for testis length before necropsy were analysed by two way repeated measures analysis of variance (comparisons of each treatment group with the control group in separate analyses within each generation). Organ masses were analysed as a proportion of body weight $\left(\mathrm{mg} \mathrm{kg}^{-1}\right)$. The severity scores for the histopathological lesions, organ and body weights were tested by analysis of variance followed by Dunnett's post hoc test (Sokal and Rohlf, 1969). Proportions are expressed as percentage values and all other data are presented as means \pm SEM.

\section{Results}

No overt signs of toxicity were noted. A total of nine mink died during this study (CON, $n=3$; LIN, $n=2$; CAR, $n=2$; PCP, $n=2$ ). Necropsies were performed on each of these mink and the cause of death was not deemed to be the pesticide treatments. Data from these mink were discarded.

The pesticides did not cause any consistent decrease in body weight during the study. Body weights for the second generation control, Lindane-, Carbofuran-, and PCP-treated mink at weaning were $504.0 \pm 46.3,482.0 \pm 76.2,588.9 \pm 23.2$, $564.8 \pm 33.5 \mathrm{~g}(P>0.05)$, respectively. Body weights for the second generation females did not differ at the time of breeding (CON, 1132.2 \pm 79.3 ; LIN, 1014.4 \pm 60.0 ; CAR, $1171.3 \pm 44.4$; 
PCP, $1143.8 \pm 34.0 \mathrm{~g} ; P>0.05)$ or at the end of lactation (CON, 987.5 \pm 60.8 ; LIN, 961.8 \pm 44.1 ; CAR, 1080.0 \pm 57.1 ; PCP, $960.0 \pm 35.5 \mathrm{~g} ; P>0.05$ ). At the time of necropsy of the second generation male mink, the PCP-treated mink were heavier than the control mink $(P<0.05)$, whereas the Lindaneand Carbofuran-treated mink did not differ significantly (CON, $1660.0 \pm 43.1$; LIN, 1587.1 \pm 61.6 ; CAR, 1897.5 \pm 77.9 ; PCP, $1946.7 \pm 79.7 \mathrm{~g}$ ). The growth rate of the third generation kits up to weaning at 8 weeks of age was unaffected by any pesticide treatment (kit weaning weight: CON, $454.5 \pm 39.9$; LIN, 553.8 \pm 58.3; CAR, $532.5 \pm 18.76$; PCP, $432.6 \pm 65.7 \mathrm{~g}$ ). However, body weight was significantly greater in the Carbofuran-treated third generation female mink than in the control mink $(P<0.05)$ at the time of necropsy $(\mathrm{CON}$, $856.7 \pm 30.0 ;$ LIN, 996.2 $\pm 33.8 ;$ CAR, $1080.2 \pm 43.0 ;$ PCP, $944.5 \pm 46.7 \mathrm{~g}$ ). Control and pesticide-treated third generation male mink did not differ in weight at the time of necropsy $(P>0.05 ; C O N, 1374.3 \pm 107.1$; LIN, $1412.5 \pm 74.6 ; C A R$, $1682.5 \pm 73.3$; PCP, $1580.0 \pm 80.8 \mathrm{~g}$ ).

Feed intake was unaffected by the pesticide treatments (overall mean of all time points for male and female second generation mink: CON, 284 $\pm 15,235 \pm 23$; LIN, 310 \pm 22 , $243 \pm 12 ; \quad$ CAR, $267 \pm 25, \quad 269 \pm 53 ; \quad P C P, \quad 275 \pm 21$, $216 \pm 40 \mathrm{~g}$ of wet feed day ${ }^{-1}$, respectively).

\section{Fertility}

The treatments had no significant effect on the proportion of the second generation mink that accepted the first mating (CON, $75 \%$; LIN, 100\%; CAR, $50 \%$; PCP, $100 \%$ ), or the proportion of mink bred at the first mating that subsequently accepted the second mating (CON, 100\%; LIN, 100\%; CAR, $75 \%$; PCP, 100\%). The average date, of both the first and the last matings for each treatment group were also not affected by the pesticide treatments (CON, March $14.7 \pm 2.1,22.8 \pm 2.2$; LIN, March 11.8 $\pm 2.0,20.1 \pm 2.1$; CAR, March $11.8 \pm 2.3$, $17.8 \pm 1.0 ;$ PCP, March 11.5 $\pm 1.4,19.9 \pm 1.5$, respectively). The proportion of mated mink that subsequently whelped (Fig. 1) tended to be reduced by the Lindane $(P<0.1)$ treatment. Implantation sites were not visible at necropsy, as the mink were killed a number of months after parturition. The litter size of mink that whelped (Fig. 1) was decreased by the Lindane treatment $(P<0.05)$. The pesticide treatments did not significantly affect the whelping date $(\mathrm{CON}$, May $8.5 \pm 2.1$; LIN, May 11.4 \pm 2.3 ; CAR, May 11.5 \pm 2.5 ; PCP, May $11.4 \pm 2.1$ ) or the duration of gestation (when calculated as the number of days from the last mating until whelping: $C O N$, $48.8 \pm$ 1.5; LIN 50.0 \pm 2.0 ; CAR, 55.0 \pm 5.0; PCP, $52.1 \pm 2.9$ ). There were no significant differences in the proportion of third generation male or female kits weaned.

\section{Endocrinology}

The only consistent treatment-related effect on the endocrine parameters measured was a decrease in serum thyroxine secretion in the PCP-treated mink compared with the control mink (Fig. 2). This decrease was statistically significant in both generations of male mink but in only the third generation of female mink $(P<0.05)$. In the second generation males,
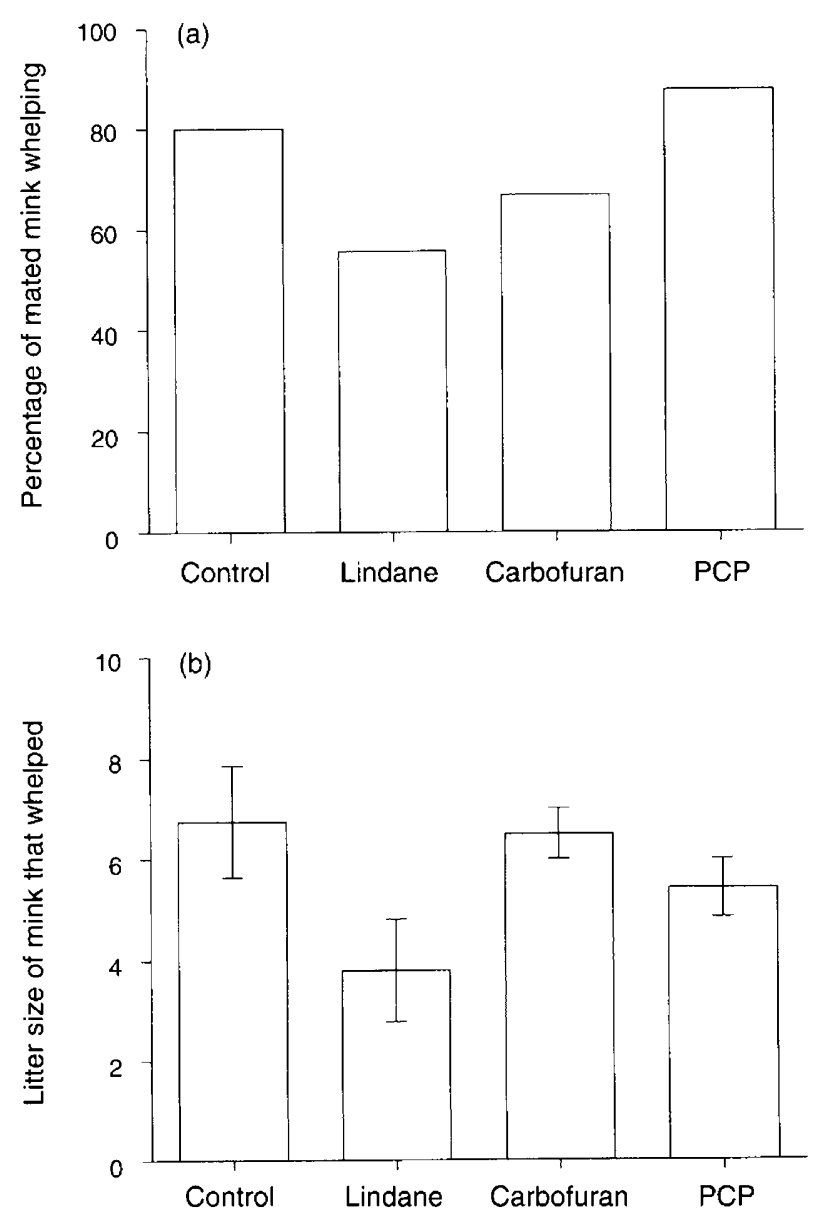

Fig. 1. (a) Whelping rate (\%) of mated mink and (b) litter size (mean \pm SEM) of mink that whelped, in second generation females fed a control diet or a diet treated with Lindane $\left(1 \mathrm{mg} \mathrm{kg}^{-1} \mathrm{day}^{-1}\right)$, Carbofuran (0.05 $\mathrm{mg} \mathrm{kg}^{-1} \mathrm{day}^{-1}$ ) or Pentachlorophenol (PCP) (1 mg $\mathrm{kg}^{-1}$ day ${ }^{-1}$ ) from conception onwards. The proportion of mated mink that subsequently whelped was reduced by the Lindane treatment $(P<0.1)$. The litter size of mink that whelped was decreased by Lindane treatment $(P<0.05)$.

thyroxine concentration was also significantly decreased $(P<0.05)$ in the Lindane- and Carbofuran-treated mink compared with the control mink.

Serum oestradiol concentrations were not affected by the pesticide treatments in any generation $(P>0.05)$ (oestradiol pmol $l^{-1}$ in the second generation females: CON, $18.1 \pm 4.4$; LIN, $9.9 \pm 1.1 ; \quad$ CAR, $15.1 \pm 3.7 ; \quad P C P, \quad 13.6 \pm 2.6$; third generation females: CON, $18.7 \pm 2.9$; LIN, $25.7 \pm 2.9$; CAR, $21.3 \pm 3.7 ; \mathrm{PCP}, 18.4 \pm 2.6$; second generation males: $\mathrm{CON}$, $44.0 \pm 4.4 ;$ LIN, $38.5 \pm 4.8$; CAR, 42.6 $\pm 4.8 ;$ PCP, $56.2 \pm 7.0$; third generation males: CON, $49.9 \pm 5.9$; LIN, $41.1 \pm 2.9$; CAR, $56.9 \pm 1.8 ;$ PCP, $48.1 \pm 5.1$ ).

Serum concentrations of cortisol were only measured in the second generation female mink as they varied greatly among individuals but were not affected by any pesticide treatment $\left(P>0.05\right.$ : cortisol nmol $1^{-1}$ : CON, 20.8 \pm 8.4 ; LIN, 44.1 \pm 26.6; CAR, $21.6 \pm 13.7$; PCP, $54.8 \pm 26.3$ ).

Serum testosterone concentrations were not affected by the pesticide treatments in the male mink $(P>0.05)$ (testosterone nmol $l^{-1}$ in the second generation: CON, $15.1 \pm 2.5$; LIN, 
(a)

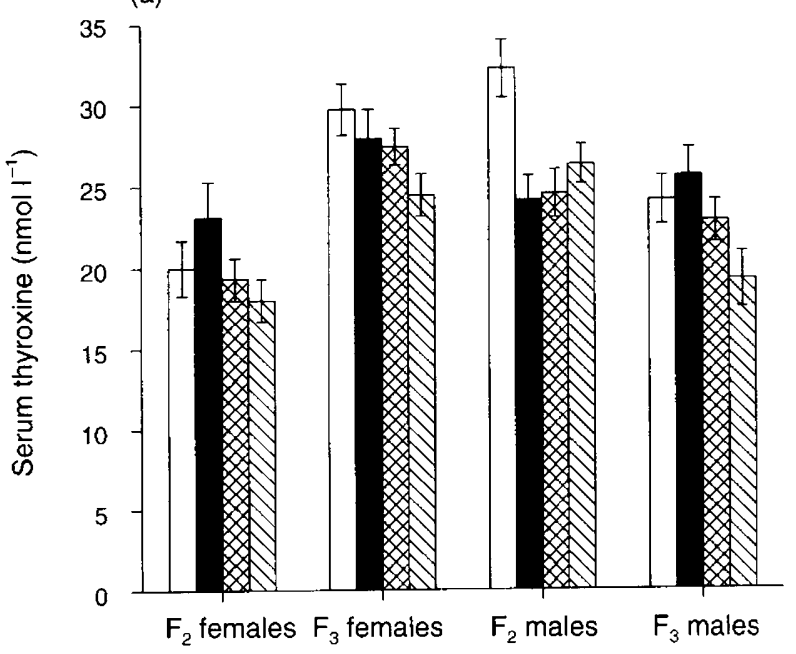

(b)

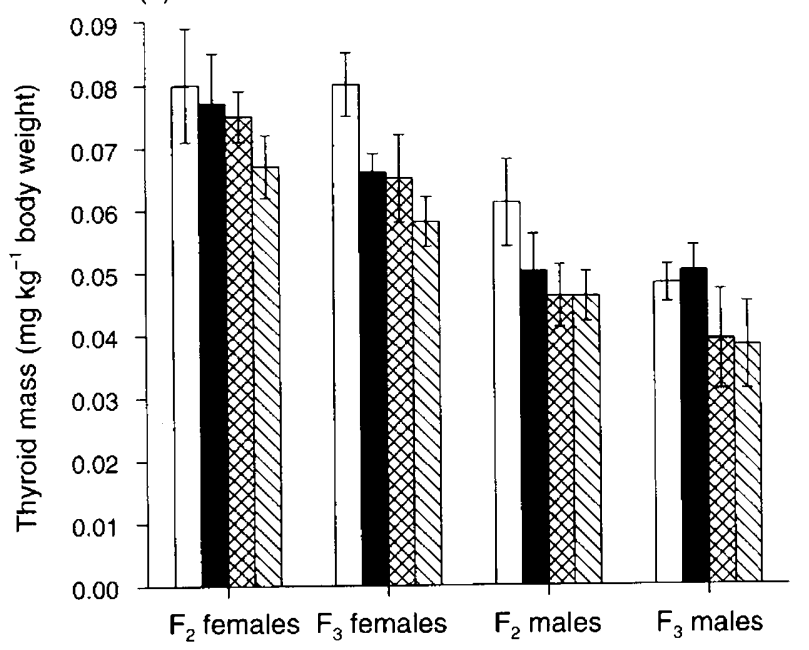

Fig. 2. (a) Serum thyroxine concentration (nmol ${ }^{-1}$, mean \pm SEM) and (b) thyroid mass ( $\mathrm{mg} \mathrm{kg}^{-1}$ body weight, mean \pm SEM) in second generation female $\left(\mathrm{F}_{2}\right.$ females), third generation female $\left(\mathrm{F}_{3}\right.$ females), second generation male $\left(\mathrm{F}_{2}\right.$ males), and third generation male $\left(\mathrm{F}_{3}\right.$ males) mink fed a control diet $(\square)$ or a diet treated with Lindane ( ( $1 \mathrm{mg} \mathrm{kg}{ }^{-1}$ day $^{-1}$ ), Carbofuran (ख) $\left(0.05 \mathrm{mg} \mathrm{kg}^{-1}\right.$ day $^{-1}$ ) or Pentachlorophenol $(\mathrm{PCP})(\mathbb{Q})\left(\mathrm{I} \mathrm{mg} \mathrm{kg}{ }^{-1}\right.$ day $\left.^{-1}\right)$. Thyroxine concentration was decreased $(P<0.05)$ in $\mathrm{F}_{3}$ male and $\mathrm{F}_{3}$ female mink treated with $P C P$ and in $F_{2}$ male mink treated with $P C P, C$ Carbofuran and Lindane, compared with control mink. Thyroid mass was decreased $(P<0.05)$ in the PCP-treated $\mathrm{F}_{3}$ female mink compared with that in the control mink.

$11.8 \pm 2.9 ; \mathrm{CAR}, 16.4 \pm 3.7 ; \mathrm{PCP}, 22.2 \pm 5.5$; third generation: CON, 19.1 $\pm 3.1 ; L I N, 16.3 \pm 1.4 ;$ CAR, $27.8 \pm 2.1 ;$ PCP, $17.7 \pm 3.1$ ).

\section{Necropsy}

The only significant differences in organ mass at necropsy were changes in thyroid, adrenal and testis mass (see below). Few treatment-specific lesions were seen when tissues were examined histologically. The severity of treatment-related lesions was significantly affected only in adrenal, testis and
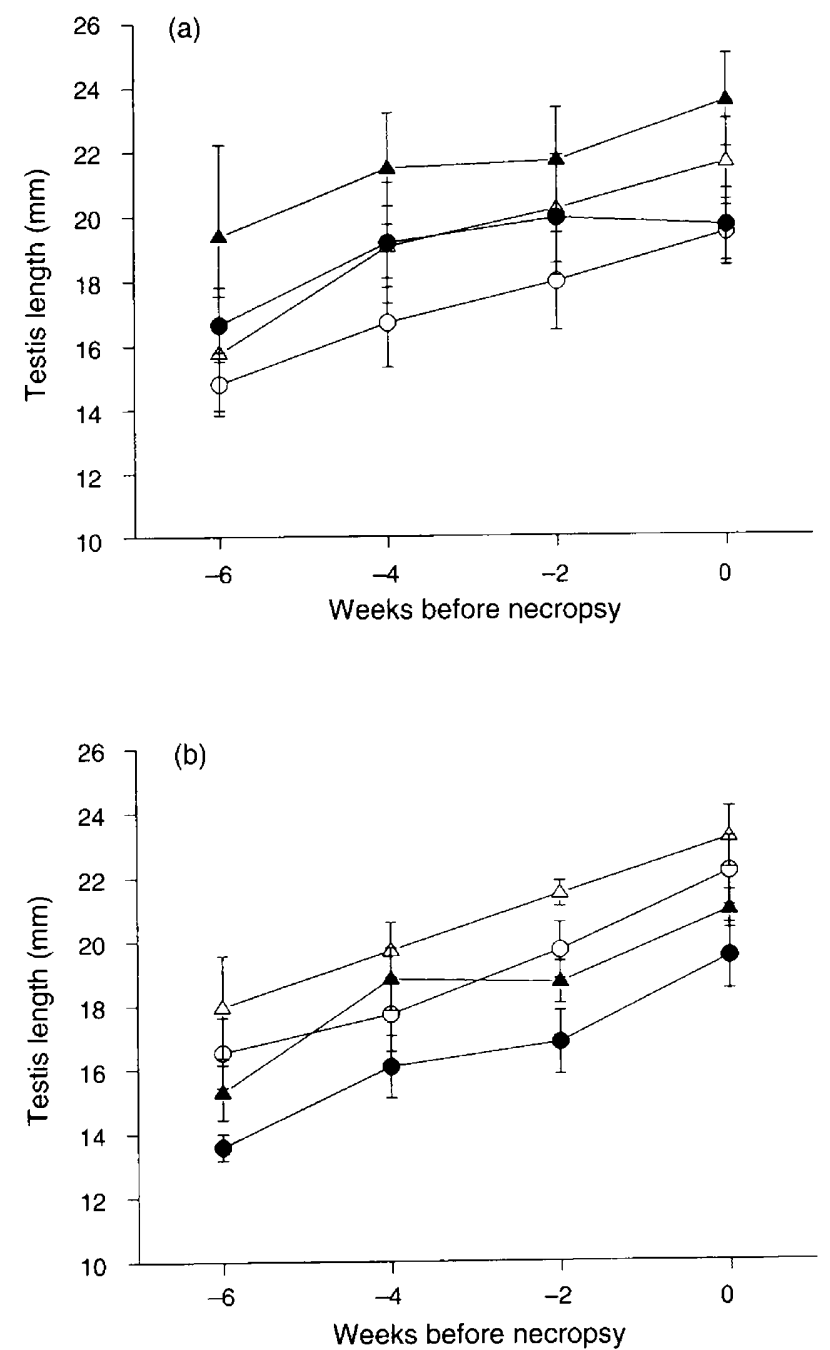

Fig. 3. Testicular development (mean length \pm SEM) in the 6 weeks before necropsy (late January) in (a) second generation male and (b) third generation male mink fed a control diet $(O)$ or a diet treated with Lindane $(\mathbf{O})\left(1 \mathrm{mg} \mathrm{kg}{ }^{-1} \mathrm{day}^{-1}\right)$, Carbofuran $(\triangle)(0.05 \mathrm{mg}$

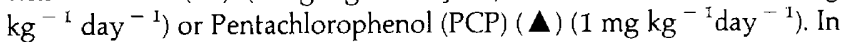
the second generation, testis length in the PCP-treated mink was consistently greater than in the control males $(P=0.05)$. In the third generation, testis length was consistently smaller in the Lindanetreated mink than in the control mink $(P=0.05)$.

prostate tissues in certain generations of mink (see below). All other noted lesions did not differ statistically in severity between treatment and control mink.

\section{Male reproductive tissues}

Testicular growth in the second generation mink occurred in a linear manner in the 6 weeks before necropsy (Fig. 3), resulting in a significant time effect $(P<0.05)$. During this time, the mean testis length in the PCP-treated mink was consistently greater than in the control mink $(P=0.05)$. When testicular growth was analysed accounting for body weight, there were no significant differences among groups $(P>0.05)$. Testis length, when measured after the testes were removed 
from the scrotum at necropsy, did not show any significant differences among groups (left and right testis length $(\mathrm{mm})$ : CON, 17.4 \pm 0.8, 17.1 \pm 1.0 ; LIN, $16.7 \pm 1.2,16.0 \pm 1.3$; CAR, $18.0 \pm 1.1,18.2 \pm 1.0$; PCP, $20.1 \pm 1.4,19.2 \pm 0.8$, respectively). Testis mass did not differ among treatments in the second generation mink $(P>0.05$; left and right testis mass $\left(\mathrm{mg} \mathrm{kg}^{-1}\right)$ : CON, $1.13 \pm 0.14,1.07 \pm 0.14$; LIN, $1.11 \pm 0.16$, $1.00 \pm 0.15 ; \mathrm{CAR}, 0.99 \pm 0.12,1.02 \pm 0.14 ; \mathrm{PCP}, 1.11 \pm 0.24$, $1.07 \pm 0.14$, respectively).

Testicular growth in the third generation mink occurred in an approximately linear manner before necropsy (Fig. 3), resulting in a significant time effect $(P<0.05)$. Testis length was consistently smaller in the Lindane-treated mink than in the control mink $(P=0.05)$ and this effect remained significant when testis mass was expressed as a proportion of body weight $(P<0.05)$. When testis length was measured after the testes had been removed from the scrotum at necropsy, the Lindane-treated mink were shown to have shorter testes (left and right testis length (mm): CON, $20.0 \pm 1.0,19.9 \pm 0.5$; LIN, $17.8 \pm 1.1, \quad 17.3 \pm 1.0 ; \quad$ CAR, $21.3 \pm 0.9,21.0 \pm 1.2 ; \quad P C P$, $18.8 \pm 0.7,18.2 \pm 0.7$, respectively), although the measurements were significantly different only when the right testis was considered $(P<0.05)$. When the testis lengths were expressed as a proportion of body weight, the difference was not found to be significant. However, testis mass was significantly lower in the Lindane-treated mink $(P<0.05)$ compared with the control mink (left and right testis mass ( $\mathrm{mg} \mathrm{kg}^{-1}$ ): CON, $1.51 \pm 0.13,1.40 \pm 0.12$; LIN, $0.99 \pm 0.08,0.89 \pm 0.10$; CAR, $1.43 \pm 0.12,1.37 \pm 0.10 ; \mathrm{PCP}, 1.26 \pm 0.14,1.14 \pm 0.14$, respectively).

In the second generation male mink, in both the left and right testes, interstitial cell hyperplasia occurred with greater severity in PCP-treated mink compared with control mink $(P<0.05)$. An increased severity of interstitial cell hyperplasia was also noted in the right testis in Carbofuran-treated mink but not in the left testis (severity scores for both testes: CON, $1.0 \pm 0.3,0.6 \pm 0.3 ;$ LIN, $1.0 \pm 0.2,1.1 \pm 0.1 ;$ CAR, $1.3 \pm 0.2$, $1.5 \pm 0.2 ; \mathrm{PCP}, 2.3 \pm 0.3,2.5 \pm 0.3$ ). The severity of cystic hyperplasia in the prostate gland was significantly increased in the PCP-treated mink compared with the control mink in which there were no recorded incidences of this particular lesion (severity scores: CON, $0.0 \pm 0.0 ; \quad$ LIN, $0.0 \pm 0.0$; CAR, $0.7 \pm 0.3 ; \mathrm{PCP}, 0.9 \pm 0.4)$. Fifty per cent of the PCP-treated mink had mild multifocal cystic hyperplasia, and this tended to be associated with a higher serum testosterone concentration $\left(28.4 \pm 9.1 \mathrm{nmol} \mathrm{l}^{-1}\right)$ than in those PCP-treated mink that did not display this prostate lesion $\left(14.1 \pm 2.0 \mathrm{nmol} \mathrm{l}^{-1}\right)$.

\section{Thyroid}

The most consistent treatment-related effect on the organ masses measured was a decrease in thyroid mass in the PCP-treated mink compared with the control mink (Fig. 2). This decrease was apparent in all generations of mink but was statistically significant only in the third generation of female mink $(P<0.05)$.

\section{Adrenal}

Adrenal mass was altered by the pesticide treatments but the effects were not consistent between generations. In the second generation females, adrenal size was increased in the Lindaneand PCP-treated mink compared with the controls, while Carbofuran-treated mink were not affected. In the third generation female mink, adrenal size was decreased in the Carbofuran-treated mink compared with the controls, while the Lindane- and PCP-treated mink did not differ significantly. Adrenal size was not affected by any pesticide treatment in the male mink (adrenal mass $\left(\mathrm{mg} \mathrm{kg}^{-1}\right)$ in the second generation females: CON, $0.105 \pm 0.009$; LIN, $0.155 \pm 0.009$; CAR, $0.125 \pm 0.007$; PCP, $0.149 \pm 0.008$; third generation females: CON, $0.150 \pm 0.008$; LIN, $0.128 \pm 0.005$; CAR, $0.113 \pm 0.005$; PCP, $0.146 \pm 0.013$; second generation males: CON, $0.106 \pm 0.011 ; \mathrm{LIN}, 0.095 \pm 0.010 ; \mathrm{CAR}, 0.090 \pm 0.004 ; \mathrm{PCP}$, $0.092 \pm 0.008$; third generation males: $\mathrm{CON}, 0.095 \pm 0.006$; LIN, $0.117 \pm 0.011$; CAR, $0.081 \pm 0.005 ;$ PCP, $0.086 \pm 0.011$ ).

In the second generation female mink, vacuolation of the cells in the zona fasiculata of the adrenal cortex was seen in all animals in all groups. However, the severity of this lesion was significantly reduced in both adrenals in the PCP- and Carbofuran-treated mink (severity scores for both adrenals: CON, $2.7 \pm 0.2,2.6 \pm 0.2 ;$ LIN, $2.3 \pm 0.2,2.4 \pm 0.2 ;$ CAR, $1.4 \pm 0.3, \quad 1.7 \pm 0.2 ; \mathrm{PCP}, \quad 1.6 \pm 0.2,1.6 \pm 0.2$, respectively; $P<0.05$ ).

In the third generation male mink, there was a significant reduction in cytoplasmic vacuolation in the cortex of both adrenals in the Carbofuran- $(P<0.05)$ and PCP-treated $(P<0.05)$ mink (severity scores for both adrenals: CON, $4.0 \pm 0.0,4.0 \pm 0.0$; LIN, $3.0 \pm 0.3,3.0 \pm 0.3 ;$ CAR, $1.8 \pm 0.5$, $2.0 \pm 0.6 ; \mathrm{PCP}, 2.5 \pm 0.6,2.3 \pm 0.5$ ).

\section{Tissue concentration of pesticides}

Concentrations of Lindane in adipose tissue samples from control female mink were $<0.005 \mathrm{mg} \mathrm{kg}^{-1}$ (the detection limit for the assay). Concentrations from Lindane-treated third generation female mink were $4.42 \pm 1.77 \mathrm{mg} \mathrm{kg}^{-1}(P<0.05)$. Concentrations of $\mathrm{PCP}$ in liver ( $\mathrm{mg} \mathrm{kg}^{-1}$ ) were: $\mathrm{CON}$, $0.014 \pm 0.00 ;$ PCP, $2.28 \pm 0.61 ; P<0.05)$.

\section{Discussion}

Lindane treatment caused a numerically similar decrease in whelping rate to that seen in our two earlier studies, in which female mink were treated with the same dose of pesticides for 3 or 6 weeks before mating (Beard et al., 1997). However, in the present study, litter size was severely reduced by the Lindane treatment compared with the untreated control mink. Thus, the overall negative impact on prolificacy was far greater in mink treated from conception (second generation mink in the present study) compared with mink treated from just before mating (Beard et al., 1997). Exposure to Lindane either in utero, during sexual differentiation, or postnatally during reproductive development, may have caused the increased severity of infertility. It has been suggested that pesticide exposure in utero may be particularly harmful as organogenesis may be affected (Guillette et al., 1996). Lindane accumulates in lipid stores during exposure and is released subsequently from these maternal depots during pregnancy. It can cross the placenta readily and be detected in the fetus (Khanna et al., 1991). 
However, in quantitative terms, the maternal milk may be an even more important source of Lindane exposure to the neonate (Pompa et al., 1994; Nair et al., 1996). Lindane has been shown to be anti-oestrogenic in that it blocks the response of oestrogen-dependent tissues to oestradiol (Chadwick et al., 1988; Cooper et al., 1989; Laws et al., 1994). This could be critical during sexual differentiation and early reproductive development. The effects of prenatal or postnatal exposure to Lindane may not be apparent immediately and indeed may only be manifest after puberty.

Mink may be a sensitive model species for testing the effects of environmental contaminants on reproduction. A threegeneration study in rats using 5-25 times higher dietary concentrations of Lindane than those used in the present study failed to show any adverse effects on reproductive function (Palmer ef al., 1978). In contrast, studies in pregnant mice have shown that Lindane causes a decrease in whelping rate and litter size (Sircar and Lahiri, 1989). These effects of Lindane on fertility may be due to a decreased rate of steroidogenesis (Sircar and Lahiri, 1990), which would adversely affect the steroid hormone-dependent changes necessary for pregnancy maintenance. Lindane has been shown to influence steroid hormone production (Srivastava and Raizada, 1993; Tiemann et al., 1996), althought it did not decrease oestradiol concentrations when given to rodents (Laws et al., 1994).

In the present study, Lindane had no effect on mating behaviour. This contrasts with the results obtained in mink treated with the same dose of Lindane for just a short time before mating, in which the second of two matings 7 days apart was not accepted by the majority of the mink (Beard et al., 1997). The reason why a prolonged exposure would negate the effect on sexual receptivity seen previously after short-term treatment is unclear. Cooper et al. (1989) observed that longterm treatment with Lindane at doses as low as $5 \mathrm{mg} \mathrm{kg}^{-1}$ day ${ }^{-1}$ delayed the onset of regular oestrous cycles in rats. In the present study, mink from all treatment groups mated during the selected breeding season. However, onset of oestrus is seasonally determined in mink and, although Lindane has been shown to influence prolactin (Cooper et al., 1989) and melatonin (Attia et al., 1990) secretion in rats, chronic treatment at low concentrations appears to have no effect on seasonality in mink.

PCP and Carbofuran had no effect on whelping rate or mating response. This negative result supports the previous finding after short-term Carbofuran exposure; however, a short-term PCP treatment previously caused a decreased mating response at the second mating and a decreased whelping rate (Beard et al., 1997). This discrepancy in the results between the short- and long-term PCP exposures may reflect a refractiveness that developed with time, but the mechanism is unclear.

The measurements in vivo of testicular length appeared to indicate a larger testis size in the PCP-treated mink. However, as measurements at necropsy failed to support this, it is assumed that the difference in vivo was probably the result of increased scrotal fat in the heavier PCP-treated males. The increased severity of cystic hyperplasia in the prostate gland and interstitial hyperplasia in the testes of PCP-treated mink is of interest, as these lesions may be related to the PCP-induced hypothyroidism. However, these lesions were not as severe in the third generation mink, and this may represent a refractoriness that develops during long-term exposure to PCP. Lindane treatment caused a decrease in testis size in the third generation males. This effect may again be related to the negative action of Lindane on steroid synthesis (Srivastava and Raizada, 1993; Tiemann et al., 1996), although serum testosterone concentrations were not significantly depressed in the present study. Chronic treatment with large doses of Carbofuran has been shown to result in testicular degeneration in male beagles (for review see Gupta, 1994); however, similar effects were not seen with the dose of Carbofuran used in the present study.

There were no significant effects of pesticide treatment on cortisol or oestradiol concentrations in serum. Differences among treatments in adrenal mass and vacuolation of cells within the adrenal gland were not reflected in altered serum concentrations of cortisol and are, therefore, difficult to interpret. PCP did cause a decrease in serum thyroxine concentration. Decreased thyroxine secretion is a common effect of PCP exposure in a number of species (calves: Hughes et al., 1985; rats: Van Raaij et al., 1991a; humans: Gerhard et al., 1991; sheep: Beard et al., 1996). Total thyroxine concentrations were inversely related to serum PCP concentrations in rats (Van Raaij et al., 1991a) and decreased concentrations of triiodothyronine, thyroxine and thyroid stimulating hormone in PCP-treated rats led Jekat et al. (1994) to suggest that the major mode of action of PCP was at the pituitary or hypothalamus. However, other studies have shown that PCP lowers plasma thyroid hormone concentrations through interference with hormone transport carriers (Van den Berg, 1990). PCP and hexachlorobenzene also reduce the uptake of thyroxine into cerebrospinal fluid, affecting the supply of thyroxine to the brain (Van Raaij et al., 1994). Although not observed in the present study, decreased thyroxine concentrations in serum and cerebrospinal fluid could, in the long term, have serious effects on sexual development, seasonality of reproduction, and adequate brain development and function (Dahl et al., 1994; Karsh et al., 1995; Parkinson et al., 1995; Cooke, 1996; Robinson et al., 1996; Piosik et al., 1997; Thrun et al., 1997). For example, Cooke et al. (1996) showed that a temporary decrease in thyroxine secretion, caused by exposure of neonatal rats to polychlorinated biphenyls, increased Sertoli cell proliferation and permanently increased adult testis size and sperm production. The reasons why PCP failed to invoke similar testicular effects in the present study, despite causing a decrease in thyroxine secretion, are unclear. Possible explanations include differences among studies in the degree of thyroxine suppression, additional direct inhibitory effects of PCP on testis development and species specificity.

An important question is the relevance of these studies to pesticide exposure of wild and domestic animals, and humans. The concentration of Lindane in human adipose tissue collected in Italy was $104 \pm 19.6 \mu \mathrm{g} \mathrm{kg}^{-1}$, and the total organochlorine load was $>1 \mathrm{mg} \mathrm{kg}^{-1}$ (Gallelli et al., 1995). In India, where the use of Lindane is particularly widespread, total hexachlorocyclohexane concentrations of $1.9 \mathrm{mg} \mathrm{kg}^{-1}$ in human adipose tissue were detected (Jani et al., 1988). In Poland, field-living roe deer were found to have $0.5 \mathrm{mg} \mathrm{kg}^{-1}$ Lindane in fatty tissue (Krynski et al., 1982) but a selection of game animals from a more recently collected sample in Poland had a total hexachlorocyclohexane concentration ranging from 15 to 
$77 \mu \mathrm{kg}^{-1}$ fat (Falandysz and Kannan, 1992). Lindane was not detected above $I \mu \mathrm{g} \mathrm{kg}^{-1}$ in mink adipose tissue collected in Iowa between 1970 and 1971; however, samples of brain were found to contain between 10 and $40 \mathrm{~g} \mathrm{~kg}^{-1}$ (Franson et al., 1974). Therefore, although the concentrations of Lindane measured in mink in the present study were high compared with most concentrations measured in human and animal populations, the severity of the effects on fertility is of concern, and many populations of wild animals could have fairly direct exposure to Lindane when it is used in crop production. Wild mink populations may be exposed to a mixture of pesticides and other persistent synthetic chemicals (Franson et al., 1974; Giesy et al., 1994; Osowski et al., 1995) which may have additive or synergistic effects (Wren, 1991). Tissue concentrations of PCP in wild populations are less widely published, but the liver concentration detected in calves fed $1 \mathrm{mg}$ PCP $\mathrm{kg}^{-1}$ for 6 weeks was $1.13 \pm 0.04 \mathrm{mg} \mathrm{kg}^{-1}$ (Hughes et al., 1985), which is in general agreement with the results of the present study from mink given the same dose, for a longer period. The mean concentration of PCP in the livers of pigs raised on contaminated wood shavings was $342 \mu \mathrm{g} \mathrm{kg}^{-1}$ (Butler and Frank, 1991) and similar concentrations were seen in five randomly selected pig liver samples collected in Canada in 1980 (range 70-340 $\mathrm{g} \mathrm{kg}^{-1}$; Ryan et al., 1985).

In summary, the present study showed that long-term exposure of female mink to Lindane (in utero, during sexual maturation, breeding and pregnancy) caused a decrease in fertility, through a reduction in whelping rate and litter size. Lindane-treated mink produced $60 \%$ fewer kits than control mink, which is a more severe reduction than that seen after a short-term exposure (Beard et al., 1997). Lindane also caused a reduction in testis size after long-term exposure in the third generation mink. PCP and Carbofuran had no effect on fertility after long-term exposure. However, PCP consistently caused a decrease in serum thyroxine concentration.

The authors thank S. J. Cook for technical assistance throughout the study, E. Rasmussen and the staff of the ACU for care and management of the mink, A. C. McRae for help setting up this study, R. B. Miller for the histopathological evaluations, and P. Bartlewski, R. K. Chandolia, A. Honaramooz and D. Waldbillig for help with the mink necropsies. This research was funded by the Canadian Network of Toxicology Centres and the Canadian Mink Breeders Association.

\section{References}

Allen AL, Doige CE, Haas SD, Card CE and Fretz PB (1995) Concentrations of triiodothyronine and thyroxine in equine fetal serum during gestation Biology and Reproduction Monograph $149-52$

Antunes-Madeira MC and Madeira VMC (1985) Partition of lindane in synthetic and native membranes Biochimica Biophysica Acta 820165

Attia AM, Mostafa MH, Soliman SA, el Sebae AH, Nonaka KO, Withyachumnarnkul B and Reiter RJ (1990) The organochlorine insecticide 1,2,3,4,5,6-hexachlorocyclohexane (lindane) but not 1,1,1-trichloro-2,2bis(p-chlorophenyl)ethane (DDT) augments the nocturnal increase in pineal $\mathrm{N}$-acetyltransferase activity and pineal and serum melatonin levels Neurochemical Research 15 673-680

Aulerich RJ, Ringer RK and Iwamoto S (1973) Reproductive failure and mortality in mink fed on Great Lakes fish Journal of Reproduction and Fertility $19365-376$

Backlin B-M and Bergman A (1995) Histopathology of postpartum placental sites in mink (Mustela vison) exposed to polychlorinated biphenyls or fractions thereof APMIS 103 843-854
Basrur PK and Ramos AS (1973) Seasonal changes in the accessory sex glands and gonaducts of male mink Canadian Journal of Zoology 51 1125-1132

Baukloh V, Bohnet HG, Trapp M, Heeschen W, Feichtinger W and Kemeter P (1985) Biocides in human follicular fluid Annals New York Academy of Sciences 240-250

Beard AP, Bartlewski PM and Rawlings NC (1996) Endocrine and reproductive function in ewes exposed to the organochlorine pesticides Lindane or Pentachlorophenol Journal of Reproduction and Fertility Abstract Series 18 Abstract 65

Beard AP, McRae AC and Rawlings NC (1997) Reproductive efficiency in mink (Mustela vison) treated with the pesticides Lindane, Carbofuran and Pentachlorophenol Journal of Reproduction and Fertility 111 21-28

Butler KM and Frank R (1991) Pentachlorophenol residues in porcine tissue following preslaughter exposure to treated wood shavings Journal of Food Protection 54 448-450

Calabrese EJ, Aulerich RJ and Padgett GA (1992) Mink as a predictive model in toxicology Drug Metabolism Review 24(4) 559-578

Cessna AJ, Waite DT and Constable M (1997) Concentrations of pentachlorophenol in atmospheric samples from three Canadian locations, 1994 Bulletin of Environmental Contamination and Toxicology $58651-658$

Chadwick RW, Cooper RL, Chang J, Rehnberg GL and McElroy WK (1988) Possible antiestrogenic activity of lindane in female rats Journal of Biochemistry and Toxicology 3 147-158

Colborn T (1995) Statement from the work session on environmentally induced alterations in development: a focus on wildlife Environmental Health Perspectives 103 3-5

Colborn T, vom Saal FS and Soto AM (1993) Developmental effects of endocrine-disrupting chemicals in wildlife and humans Environmental Health Perspectives 101 378-384

Cooke PS (1996) Thyroid hormone and the regulation of testicular development Animal Reproduction Science 42 333-341

Cooke PS, Zhao Y-D and Hansen LG (1996) Neonatal polychlorinated biphenyl treatment increases adult testis size and sperm production in the rat Toxicology and Applied Pharmacology 136 112-117

Cooper RL, Chadwick RW, Rehnberg GL, Goldman JM, Booth KC, Hein JF and McElroy WK (1989) Effect of lindane on hormonal control of reproductive function in the female rat Toxicology and Applied Pharmacology 99 384-394

Crum JA, Burisan SJ, Aulerich RJ, Polin D and Braselton WE (1993) The reproductive effects of dietary heptachlor in mink (Mustela vison) Archives of Environmental Contamination and Toxicology 24 156-164

Dahl GE, Evans NP, Moenter SM and Karsch FJ (1994) The thyroid gland is required for reproductive neuroendocrine responses to photoperiod in the ewe Endocrinology 135 10-15

Daston GP, Gooch JW, Breslin WJ, Shuey DL, Nikoforov AI, Fico TA and Gorsuch JW (1997) Environmental estrogens and reproductive health: a discussion of the human and environmental data Reproductive Toxicology 11 (4) 465-481

DiGregorio GB, González Reyna A and Murphy BD (1994) Roles of melatonin and prolactin in testicular crudescence in mink (Mustela vison) Journal of Reproduction and Fertility 102 1-5

Ecobichon DJ (199I) Toxic effects of pesticides. In Cassarett and Doull's Toxicology 4th Edn pp 565-622 Eds MO Amdur, J Doull and CD Klassen. Toronto, Ontario

Falandysz J and Kannan K (1992) Organochlorine pesticide and polychlorinated biphenyl residues in slaughtered and game animal fats from the northern part of Poland Zeitschrift Fuer Lebensmittel-Untersuchung und Forschung 195 $17-21$

Feldman, D (1997) Editorial: estrogens from plastic - are we being exposed? Endocrinology 138(5) 1777-1779

Foster WG (1995) The reproductive toxicology of Great Lakes contaminants Environmental Health Perspectives 103 (9) 63-69

Franson JC, Dahm PA and Wing LD (1974) Chlorinated hydrocarbon insecticide residues in adipose, liver, and brain samples from lowa mink Bulletin of Environmental Contamination and Toxicology 11 379-385

Gallelli G, Mangini S and Gerbino C (1995) Organochlorine residues in human adipose and hepatic tissues from autopsy sources in Northern Italy Journal of Toxicology and Environmental Health 46 293-300

Gerhard I, Derner M, and Runnebaum B (1991) Prolonged exposure to wood preservatives induces endocrine and immunologic disorders in women [letter] American Journal of Obstetrics and Gynecology 165(2) 487-488

Giesy JP, Vergrugge DA, Othout RA, Bowerman WW, Mora MA, Jones PD, Newsted JL, Vandervoort C, Heaton SN, Aulerich RJ, Bursian SJ, Ludwig JP, 
Dawson GA, Kubiak TI, Best, DA and Tillitt DE (1994) Contaminants in fishes from Great Lakes-influenced sections and above dams of three Michigan rivers. II: Implications for health of mink Archives of Environmental Contamination and Toxicology $27213-223$

Gray LE, Jr, Ostby J, Monosson E and Kelce WR (1994) Alterations of sex differentiation in male rats following perinatal exposure to low doses of the antiandrogenic pesticide vinclozolin (V) Biology of Reproduction 5051

Guillette LJ, Jr, Arnold SF and McLachlan JA (1996) Ecoestrogens and embryos - is there a scientific basis for concern? Animal Reproduction Science 42 13-24

Guo YL, Lambert GH and Hsu CC (1995) Growth abnormalities in the population exposed in utero and early postnatally to polychlorinated biphenyls and dibenzofurans Environmental Health Perspectives 103 (6) $117-122$

Gupta RC (1994) Carbofuran toxicity Journal of Toxicology and Environmental Health $43383-418$

Hansson A (1947) The physiology of reproduction in mink (Mustela vison, Schreb.) with special reference to delayed implantation Acta Zoologica 28 $1-136$

Heaton SN, Bursian SJ, Giesy JP, Tillitt DE, Render JA, Jones PD, Verbrugge DA, Kubiak TJ and Aulerich RJ (1995) Dietary exposure of mink to carp from Saginaw Bay, Michigan. 1. Effects on reproduction and survival, and the potential risks to wild mink populations Archives of Environmental Contamination and Toxicology 28 334-343

Hughes BJ, Forsell JH, Sleight SD, Kuo C and Shull LR (1985) Assessment of pentachlorophenol toxicity in newborn calves: clinicopathology and tissue residues Journal of Animal Science 61 1587-1603

Jani JP, Patel JS, Shah MP, Variya MR, Shah YH, Gupta S and Kashyap S (1988) Levels of dichlorodiphenyltrichloroethane and hexachlorocyclohexane in human adipose tissue of the Indian population Scandanavian Journal of Work Environmental Health 14(3) 201-204

Jekat FW, Meisel ML, Eckard R and Winterhoff H (1994) Effects of pentachlorophenol (PCP) on the pituitary and thyroidal hormone regulation in the rat Toxicology Letters 71 9-25

Karsch FJ, Dahl GE, Hachigian TM and Thrun LA (1995) Involvement of thyroid hormones in seasonal reproduction Journal of Reproduction and Fertility Supplement 49 409-422

Kavlock RJ, Daston GP, DeRosa C, Fenner Crisp P, Gray LE, Kaattari S, Lucier G, Luster M, Mac MJ, Maczka C, Miller R, Moore J, Rolland R, Scott G, Sheehan DM, Sinks T and Tilson HA (1996) Research needs for the risk assessment of health and environmental effects of endocrine disruptors: a report of the US EPA-sponsored workshop Environmental Health Perspectives 104(4) 715-740

Khanna RN, Kunwar K, Gupta R and Gupta GS (1991) Placental transport of lindane during early and late stages of gestation in rats Bulletin of Environmental Contamination and Toxicology 47 508-514

Kingsbury DL and Rawlings NC (1993) Effect of exposure to a boar on circulating concentrations of $\mathrm{LH}, \mathrm{FSH}$, cortisol and oestradiol in prepubertal gilts Journal of Reproduction and Fertility 98 245-250

Kutz FW, Wood PH and Bottimore DP (1991) Organochlorine pesticides and polychlorinated biphenyls in human adipose tissue Reviews of Environmental Contamination and Toxicology 120 1-82

Krynski A, Kaluzinski J, Delong A, Dutkiewicz M and Labudzki L (1982) Polychloride and carbamate insecticide contamination of roe deer inhabiting fields and forests Acta Theriologica 27 489-497

Larsen RV, Born GS, Kessler WV, Shaw SM and Van Sickel DC (1975) Placental transfer and teratology of pentachlorophenol in rats Environmental Letters 10 121-128

Laws SC, Carey SA, Hart DW and Cooper RL (1994) Lindane does not alter the estrogen receptor or the estrogen-dependent induction of progesterone receptors in sexually immature or ovariectomized adult rats Toxicology 92 $127-142$

Mably TA, Moore RW and Peterson RE (1992) In utero and lactational exposure of male rats to 2,3,7,8-tetrachlorodibenzo-p-dioxin Toxicology and Applied Pharmacology 114 97-107

MacNeil JD, Patterson JR, Fesser AC and Martz VK (1990) Determination of pentachlorophenol in animal tissues: a Canadian perspective Journal of the Association of Official Analytical Chemists 73 838-841

MacNeil JD, Patterson JR, Fesser AC and Martz VK (1991) Persistent organochlorine residues in game-ranched bison in Saskatchewan, Canada Bulletin of Environmental Contamination and Toxicology 46 300-304

Murphy BD and Douglas BA (1992) Reproduction in female mink. In Reproduction in Carnivorous Fur Bearing Animals pp 39-49 Eds AH Tarour and M Valtoner. Jordbrugsterlaget, Copenhagen
Nagel SC, vom Saal FS, Thayer KA, Dhar MG, Boechler M and Welshons WV (1997) Relative binding affinity-serum modified access (RBA-SMA) assay predicts the relative in vivo bioactivity of the xenoestrogens bisphenol $\mathrm{A}$ and octylphenol Environmental Health Perspectives 105 70-76

Nair A, Mandapati R, Dureja P and Pillai MKK (1996) DDT and HCH load in mothers and their infants in Delhi, India Bulletin of Environmental Contamination and Toxicology 56 58-64

Nimrod AC and Benson WH (1996) Environmental estrogenic effects of alkylphenol ethoxylates Critical Reviews in Toxicology 26(3) 335-364

Osowski AL, Brewer LW, Baker OE and Cobb GP (1995) The decline of mink in Georgia, North Carolina, and South Carolina: the role of contaminants Archives of Environmental Contamination and Toxicology 29 418-423

Palmer AK, Cozen DD, Spicer EJF and Worden AN (1978) Effects of lindane upon reproductive function in a 3-generation study in rats Toxicology 10 45-54

Parkinson TJ, Douthwaite JA and Follett BK (1995) Responses of prepubertal and mature rams to thyroidectomy Journal of Reproduction and Fertility 104 $51-56$

Piosik PA, van Groenigen M, van Doorn J, Baas F and de Vijlder JJM (1997) Effects of maternal thyroid status on thyroid hormones and growth in congenitally hypothyroid goat fetuses during the second half of gestation Endocrinology 138(1) 5-11

Pompa G, Fadini L, diLauro F and Caloni F (1994) Transfer of lindane and pentachlorobenzene from mother to newborn rabbits Pharmacology Toxicology 74 28-34

Ravindra JP, Rawlings NC, Evans ACO and Adams GP (1994) Ultrasonographic study of ovarian follicular dynamics in ewes during the oestrous cycle Journal of Reproduction and Fertility 101 501-509

Robinson JJ, Aitken RP, Atkinson T, Wallace JM and McNeilly AS (1996) Effect of continuous infusion of thyrotrophin-releasing hormone on plasma prolactin and on ovarian activity in melatonin-treated ewes Joumal of Reproduction and Fertility 107 17-22

Ryan JJ, Lizotte R, Sakuma T and Mori B (1985) Chlorinated dibenzo-p-dioxins, chlorinated dibenzofurans, and pentachlorophenol in Canadian chicken and pork samples Journal of Agricultural Food Chemistry 33 1021-1026

Sharpe RM (1995) Another DDT connection Nature 375 538-539

Sircar S and Lahiri P (1989) Lindane (c.-HCH) causes reproductive failure and fetotoxicity in mice Toxicology 59 171-177

Sircar S and Lahiri P (1990) Effect of lindane on mitochondrial side-chain cleavage of cholesterol in mice Toxicology 61(1) 41-46

Sitarska E, Klucinski W, Faundez R, Duszewska AM, Winnicka A and Goralczyk K (1995) Concentration of PCBs, HCB, DDT, and HCH isomers in the ovaries, mammary gland, and liver in cows Bulletin of Environmental Contamination and Toxicology 55 865-869

Sokal KJ and Rohlf FJ (1969) Biometry WH Freeman and Co., San Francisco

Sonawane BR (1995) Chemical contaminants in human milk: an overview Environmental Health Perspectives 103(6) 197-199

Spencer EY (1982) Guide to the Chemicals used in Crop Production 7th Edn. Agriculture Canada Research Branch, Research Centre, London, Ontario

Srivastava MK and Raizada RB (1993) Prenatal effects of technical hexachlorocyclohexane in mice Journal of Toxicology and Environmenial Health $\mathbf{4 0}$ 105-115

Sundqvist C, Amador AG and Bartke A (1989) Reproduction and fertility in the mink (Mustela vison) Journal of Reproduction and Fertility 85 413-44 I

Tate CM and Heiny JS (1996) Organochlorine compounds in bed sediment and fish tissue in the South Platte River Basin, USA, 1992-1993 Archives of Environmental Contamination and Toxicology 30 62-78

Thompson TS and Treble RG (1996) Pentachlorophenol levels in human urine Environmental Contamination and Toxicology 56 520-526

Thrun LA, Dahl GE, Evans NP and Karsch FJ (1997) Effect of thyroidectomy on maintenance of seasonal reproductive suppression in the ewe Biology of Reproduction 56 1035-1040

Tiemann U, Pöhland R and Schneider F (1996) Influence of organochlorine pesticides on physiological potency of cultured granulosa cells from bovine preovulatory follicles Theriogenology 46 253-265

Van den Berg KJ (1990) Interaction of chlorinated phenols with thyroxine binding sites of human transthyretin, albumin and thyroid binding globulin Chemico Biological Interactions 76(1) 63-75

Van Raaij JA, van den Berg KJ, Engel R, Bragt PC and Notten WR (1991) Effects of hexachlorobenzene and its metabolites pentachlorophenol and tetrachlorohydroquinone on serum thyroid hormone levels in rats Toxicology 67 $107-116$ 
Van Raaij JA, Frijters CM, Kong LW, van den Berg KJ, and Notten WR (1994) Reduction of thyroxine uptake into cerebrospinal fluid and rat brain by hexachlorobenzene and pentachlorophenol Toxicology 94(1-3) 197-208
Wren CD (1991) Cause effect linkages between chemicals and populations of mink (Mustela vison) and otter (Lutra canadensis) in the Great Lakes Basin Journal of Toxicology and Environmental Heaith 33 549-585 